Ann. Biol. anim. Bioch. Biophys., 1976, 16 (2), 145-153.

\title{
DELAYED THINNING \\ OF THICK EGG WHITE DURING STORAGE IN EGGS PRODUCED BY ACIDOTIC HENS
}

\author{
B. SAUVEUR \\ with the technical assistance of $\mathrm{J}$. ROCARD \\ Station de Recherches avicoles, \\ Centre de Recherches de Tours, I. N. R. A., \\ Nouzilly, 37380 Monnaie
}

\section{SUMMARY}

The thick white fraction of albumen obtained from acidotic eggs liquefies less rapidly than the corresponding fraction of control eggs. This reduced liquefaction is accompanied by maintenance of $\mathrm{pH}$ and divalent cation content of albumen during egg storage, while these two parameters increase or decrease, respectively, in normal eggs.

\section{INTRODUCTION}

The physicaloproperties of the thick egg white fraction seem to be linked to its divalent cation content. This proposition is valuable for the fresh egg just after laying in some particular conditions and principally during egg storage. It was shown primarily by SAUVEUR (I970) that the increase of thick albumen height due to metabolic acidosis is accompanied by a large rise $(+250 \mathrm{p}$. 100) in calcium content; magnesium content is also enhanced, although with less variation (about +55 p. IOO) (SAUveur, I974). The physical properties of thick egg white can also be increased before oviposition by plumping uterine eggs in $\mathrm{CaCl}_{2}$ or $\mathrm{MgCl}_{\mathbf{2}}$ solutions. The height of albumen gel obtained in such conditions was I 4 . I and $14.4 \mathrm{~mm}$ as against II.I mm. with a $\mathrm{NaCl}$ solution (SAUVEUR, I973 $a$ ).

During egg storage, calcium and magnesium content and albumen gel height decreased together. These two events could be delayed by using a 2 p. Ioo carbon dioxyde atmosphere around the eggs (SAUVEUR, I97I). $\mathrm{Ca}^{2+}$ and $\mathrm{Mg}^{2+}$ were shown to be able to lessen in vitro the interaction between lysozyme and reduced ovo- 
mucin (RobINson, I972), and $\mathrm{Mg}^{2+}$, added to thick egg white, retarded the natural thinning process (RoBINSON and MONSEY, I972).

The last study in this field (MONSEy and RoBInson, I974) showed that the thick egg white obtained from mature hens contained less magnesium and liquefied more rapidly than the corresponding thick white from eggs laid by young hens.

The aim of the present work is to determine whether eggs produced by acidotic hens (in which albumen divalent cation content is high) have a better capacity for storage than normal eggs.

\section{MATERIALS AND METHODS}

The eggs were obtained from 16 Warren laying hens caged singly in a controlled room $\left(20^{\circ} \mathrm{C}\right.$ and $60 \mathrm{p}$. 100 humidity). Eight birds were fed a normal layer diet, and the 8 others the same diet supplemented with $3 \mathrm{p}$. Ioo $\mathrm{NH}_{4} \mathrm{Cl}$ (acidifying diet). Three eggs of each hen were studied just after laying and after $2, \mathrm{I}_{4}$ and 28 days of storage at $20^{\circ} \mathrm{C}$ and $75 \mathrm{p}$. 100 (control group) or 85 p. roo (acidotic group) humidity. The water content of the atmosphere was voluntarily higher during the storage of acidotic eggs in order to obtain the same weight loss in the two groups; it is well known that shell thickness is greatly reduced by acidosis.

Of the three individual eggs at each stage, only two were weighed and tested for Haugh Units (HAUGH, 1937). The three albumen layers of the third one were separated and each of them tested for $\mathrm{pH}$, osmotic pressure and ionic content ( $\mathrm{Na}, \mathrm{K}, \mathrm{Ca}$ and $\mathrm{Mg}$ ). The corresponding methods have already been described (SAUVEUR, 197I).

\section{RESULTS AND DISCUSSION}

\section{Egg weight}

The mean weight of newly-laid eggs was $59.6 \pm 0.3 \mathrm{~g}$ and $57.3 \pm 0.6 \mathrm{~g}$ for the control and acidotic groups, respectively $(\mathrm{P}<0.05)$. This reduction due to acidosis was similar to that previously recorded (SAUvEUR, I974).

Variation in egg weight in relation to storage time is reported in table $\mathbf{I}$. In

TABLE I

Effect of acidosis on egg weight loss during storage $(\Delta \mathrm{P}$ in $\mathrm{g})$

\begin{tabular}{|c|c|c|c|}
\hline & \multicolumn{3}{|c|}{ Storage duration at $20^{\circ} \mathrm{C}$ (days) } \\
\hline & 2 & 14 & 28 \\
\hline Control ... & $0.14 \pm 0.01\left(^{(1)}\right.$ & $1.14 \pm 0.04$ & $2.12 \pm 0.04$ \\
\hline Acidosis $\ldots$ & $0.32 \pm 0.06$ & $2.60 \pm 0.41$ & $2.83 \pm 0.41$ \\
\hline F value $\ldots . .$. & 4.14 & 4.81 & $1 . \overline{30}$ \\
\hline Probability level ... & 0.10 & $<0.05$ & NS \\
\hline
\end{tabular}

(1) Average value \pm MSE obtained from 24 eggs. 
spite of the precautions taken to monitor relative humidity, weight loss was slightly greater in acidotic than in control eggs. However, the difference was small and not significant after 28 days of storage.

\section{Haugh units}

The evolution of Haugh units during storage was very different between the two groups (fig. I). Just after laying, the score was I3 units higher in the acidotic group in accordance with previous results (HALI and HELBACKA, I959; HUNT and AITKEN, I962; SAUVEUR, I970). The difference in favor of the experimental eggs was still more evident after storage. For instance, after I4 days of storage, Haugh unit score was two times higher in eggs obtained from acidotic than from control birds (the level of significance was $<0.0005$ for each period).

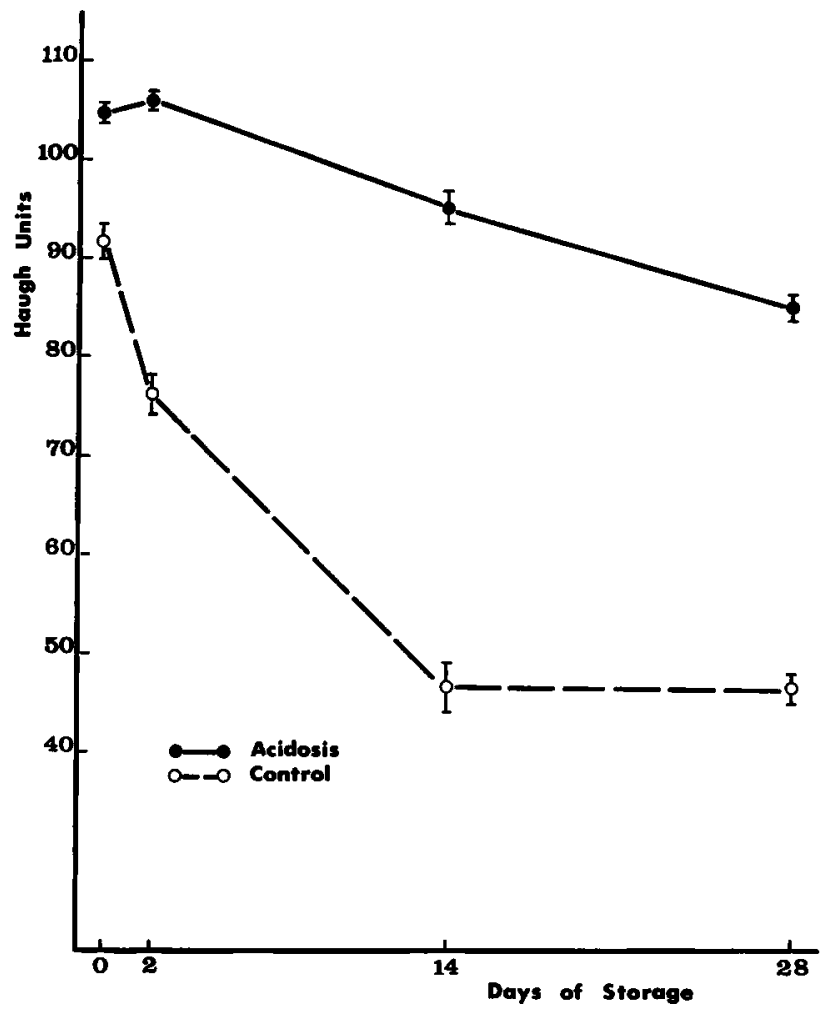

Fig. r. - Effect of metabolic acidosis on egg white thinning during storage at $20^{\circ} \mathrm{C}$

\section{Albumen water content, osmotic pressure and $p H$}

It is known that initial water content of the albumen decreases from the outside to the inside of the egg (ROMANOFF and RoMANOFr, I949). The present results confirm this fact and indicate no difference due to acidosis (table 2). 
TABLE 2

Water content of the three egg white fractions during storage (g/g dry matter)

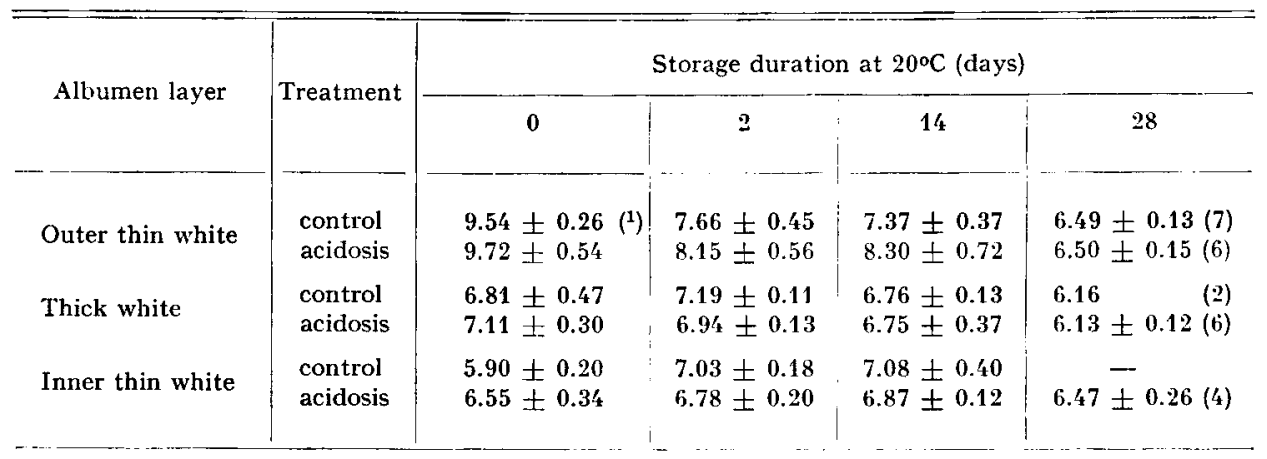

(1) Average value \pm MSE obtained from 8 eggs. After 28 days of storage the separation into three regions was often difficult, principally in control eggs; the number of studied eggs is in brackets for this stage.
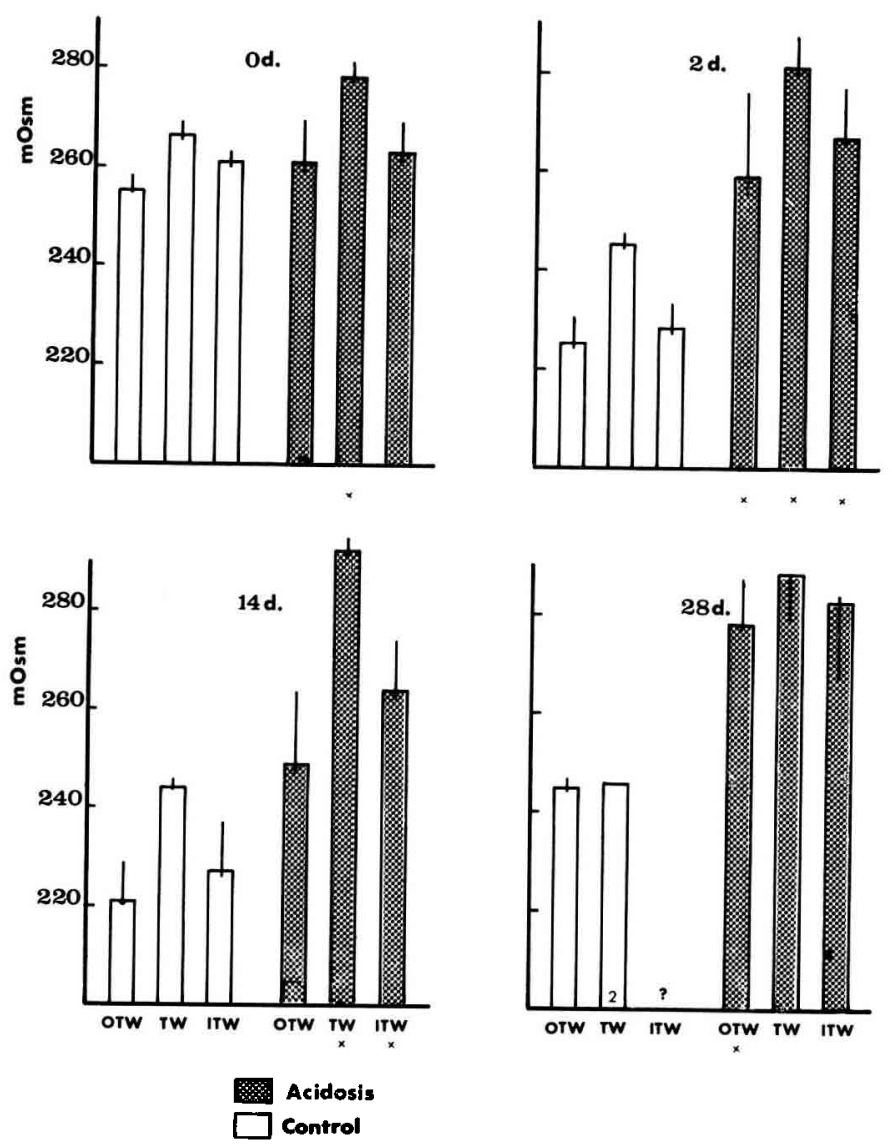

FIG. 2. - Evolution of osmotic pressure in the three albumen layers during egg storage at $20^{\circ} \mathrm{C}$. Effect of metabolic acidosis

$(x)$ : for each storage duration the experimental values underscripted with a cross were significantly different from the corresponding control values. OTW : outer thin white; TW : thick white; ITW : inner thin white. (2) mean of two values only. 
During storage, uniformization of the water content between the three regions occured very quickly; this was particularly obvious in control eggs during the first two days. At the same time, transfer of water between the outer thin white and the thick white seemed to be less pronounced in acidotic eggs. During the following storage periods, decreasing evolution towards a common value for the three albumen regions was the same for the two groups of eggs.

The osmotic pressure of the three albumen layers reflected the water content only partly (fig. 2). Thus, osmotic pressure never decreased in the acidotic group as it did in control eggs between $o$ and 2 days of storage.

Furthermore, osmotic pressure value was always higher in the thick white than in the two thin regions. This difference was more evident in acidotic than in control eggs and has been previously reported during egg storage (SAUvEUR, I97I).

The $\mathrm{pH}$ values are presented in figure 3. Just after laying, $\mathrm{pH}$ values were lowest in acidotic eggs and identical in the three regions of the albumen, contrary to the gradient which was obvious in control eggs as in previous experiments (SAUVEUR
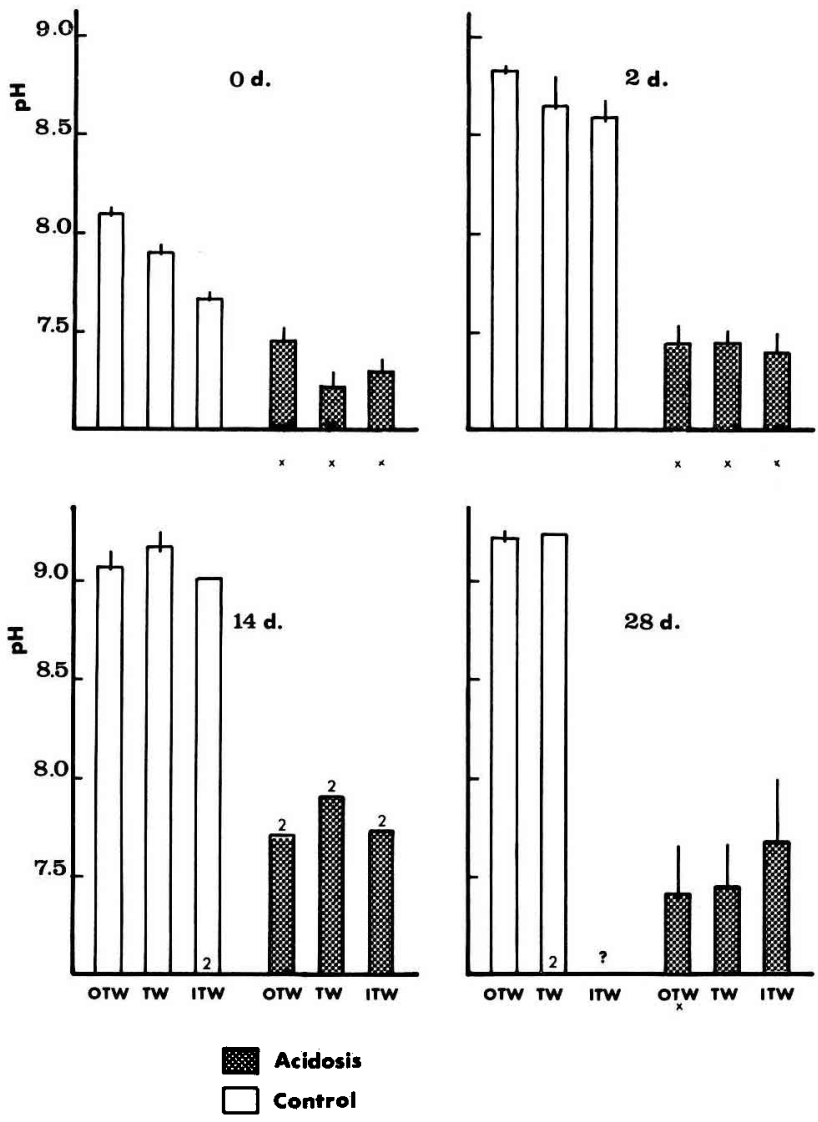

FIG. 3. - Effect of metabolic acidosis on the $p H$ values of each albumen layer during egg storage at $20^{\circ} \mathrm{C}$

$(x)$ and other signs : see foot note figure 2 
I969). The most surprising fact was the stability of acidotic albumens at a low $\mathrm{pH}$ during storage. We must conclude that this low $\mathrm{pH}$ value was due to overloading of fixed acidity and not to excess of $\mathrm{CO}_{2}$ content. Indeed, results demonstrated that albumen $\mathrm{pCO}_{2}$ is reduced by metabolic acidosis (SAUVEUR, I970) and that thinning of egg shell enhances the escape of $\mathrm{CO}_{2}$.

The $\mathrm{pH}$ stability may partly explain the absence of variation of osmotic pressure in acidotic eggs, while in normal eggs this drop is postulated to be due to stronger cation fixation on proteins when $\mathrm{pH}$ rises after egg laying (SAUVEUR, I97I). According to the hypothesis of ROBINSON and MONSEY (I972), decreasing osmotic pressure is due to dissociation of an expanded network of ovomucin-1ysozyme polymers. This is not in opposition to the present results since such a dissociation is also $\mathrm{pH}$ dependent.

\section{Albumen cation content}

Sodium and potassium levels in the albumen are reported in table 3 on a dry matter basis. This table shows that sodium content :

- decreased from the outer to the inner thin white of fresh control eggs ;

- decreased in the outer thin white of control eggs between o and 2 days;

- was reduced by acidosis whatever the albumen layer or storage time might be.

\section{TABLE 3}

Effect of acidosis on $N a$ and $K$ contents of the albumen during egg storage (mEq/kg dry matter)

\begin{tabular}{|c|c|c|c|c|c|}
\hline \multirow{2}{*}{ Albumen layer } & \multirow{2}{*}{ Treatment } & \multicolumn{4}{|c|}{ Storage duration at $20^{\circ} \mathrm{C}$ (days) } \\
\hline & & 0 & 2 & 14 & 28 \\
\hline \multicolumn{6}{|l|}{ Sodium } \\
\hline Outer thin white & $\begin{array}{l}\text { Control (C) } \\
\text { Acidosis (A) }\end{array}$ & $\begin{array}{l}862 \pm 34 \\
696 \pm 24^{* *}\end{array}$ & $\begin{array}{l}720 \pm 34 \\
573 \pm 80\end{array}$ & $\begin{array}{l}690 \pm 30 \\
513 \pm 33^{* *}\end{array}$ & $\begin{array}{l}640 \pm 27 \\
497 \pm 32^{* * *}\end{array}$ \\
\hline Thick white & $\begin{array}{l}\text { C } \\
\text { A }\end{array}$ & $\begin{array}{l}641 \pm 49 \\
515 \pm 43^{*}\end{array}$ & $\begin{array}{l}665 \pm 26 \\
501 \pm 37^{* *}\end{array}$ & $\begin{array}{l}684 \pm 22 \\
505 \pm 51^{* * *}\end{array}$ & $\begin{array}{l}575(2) \\
461 \pm 37\end{array}$ \\
\hline Inner thin white & $\begin{array}{l}\mathrm{C} \\
\mathrm{A}\end{array}$ & $\begin{array}{l}578 \pm 39 \\
442 \pm 32^{*}\end{array}$ & $\begin{array}{l}620 \pm 23 \\
455 \pm 45^{* *}\end{array}$ & $\begin{array}{l}677 \pm 29 \\
497 \pm 28^{*}\end{array}$ & $508 \overline{ \pm} 47$ \\
\hline \multicolumn{6}{|l|}{ Potassium } \\
\hline Outer thin white & $\begin{array}{l}\text { C } \\
\mathbf{A}\end{array}$ & $\begin{array}{l}374 \pm 19 \\
330 \pm 16\end{array}$ & $\begin{array}{l}323 \pm 23 \\
294 \pm 27\end{array}$ & $\begin{array}{l}295 \pm 6 \\
247 \pm 15^{* *}\end{array}$ & $\begin{array}{l}280 \pm 4 \\
261 \pm 12\end{array}$ \\
\hline Thick white & $\begin{array}{l}\mathrm{C} \\
\mathrm{A}\end{array}$ & $\begin{array}{l}279 \pm 23 \\
252 \pm 18\end{array}$ & $\begin{array}{l}282 \pm 10 \\
261 \pm 15\end{array}$ & $\begin{array}{l}299 \pm 14 \\
256 \pm 19\end{array}$ & $\begin{array}{l}283 \pm 4 \\
249 \pm 10\end{array}$ \\
\hline Inner thin white & $\begin{array}{l}\mathrm{C} \\
\mathrm{A}\end{array}$ & $\begin{array}{l}256 \pm 15 \\
227 \pm 20\end{array}$ & $\begin{array}{l}266 \pm 5 \\
245 \pm 16\end{array}$ & $\begin{array}{l}299 \pm 6 \\
243 \pm 10^{* *}\end{array}$ & $278 \pm 16$ \\
\hline
\end{tabular}

*,** : experimental value different from the corresponding control value at levels $\mathrm{P}<0.05$ and $P<0.01$, respectively. 
The first two results can be completed with previous studies showing that sodium level in the water of the albumen is constant during egg storage (SAUVEUR, I97I) and between albumen zones (SAUVEUR, I969, I973 b). Then, movements of water inside the egg after laying are accompanied by sodium translocation.

Potassium content was not very modified by treatment as is often observed in this kind of experiment. Acidosis has been shown to slightly increase potassium level in egg white, but it must be effective for a long time (SAUVEUR, I970).

Calcium and magnesium contents of the albumen are reported in table 4 . The values recorded just after laying confirm anterior results on the large increase of these cation levels under acidosis (SAUVEUR, I970, I974). It must be noted here that acidosis suppressed the storage-induced drop of divalent cations normally found in control eggs; not only were average levels very high in the acidotic group, but they remained constant during the four weeks of storage. Although mineral levels have not been recorded in egg yolk, we can assume that in acidotic eggs, divalent cations do not transfer from the white to the yolk during storage as they do in normal conditions (SAUVEUR, I97I).

TABLE 4 Effect of acidosis on $C a$ and $M g$ contents of the albumen during egg storage
(mEg/kg dry matter)

\begin{tabular}{|c|c|c|c|c|c|}
\hline \multirow{2}{*}{ Albumen layer } & \multirow{2}{*}{ Treatment } & \multicolumn{4}{|c|}{ Storage duration at $20^{\circ} \mathrm{C}$ (days) } \\
\hline & & 0 & 2 & 14 & 28 \\
\hline \multicolumn{6}{|l|}{ Calcium } \\
\hline OTW & $\begin{array}{l}\text { Control (C) } \\
\text { Acidosis (A) }\end{array}$ & $\begin{array}{c}96 \pm 6 \\
361 \pm 50\end{array}$ & $\begin{array}{c}33 \pm 2 \\
409 \pm 68\end{array}$ & $\begin{array}{c}16 \pm 1 \\
356 \pm 54\end{array}$ & $\begin{array}{c}13.4 \pm 0.4 \\
299 \pm 54\end{array}$ \\
\hline TW & $\begin{array}{l}\mathrm{C} \\
\mathrm{A}\end{array}$ & $\begin{array}{c}86 \pm 6 \\
303 \pm 39\end{array}$ & $\begin{array}{c}32 \pm 3 \\
300 \pm 63\end{array}$ & $\begin{array}{c}14 \pm 1 \\
350 \pm 45\end{array}$ & $\begin{array}{c}13(2) \\
333 \pm 65\end{array}$ \\
\hline ITW & $\begin{array}{l}\mathrm{C} \\
\mathrm{A}\end{array}$ & $\begin{array}{c}85 \pm 6 \\
281 \pm 40\end{array}$ & $\begin{aligned} 36 & \pm 3 \\
420 & \pm 96\end{aligned}$ & $\begin{aligned} 18 & \pm \mathbf{3} \\
350 & \pm 50\end{aligned}$ & $234 \overline{ \pm} 104$ \\
\hline \multicolumn{6}{|l|}{ Magnesium } \\
\hline OTW & $\begin{array}{l}\mathrm{C} \\
\mathrm{A}\end{array}$ & $\begin{array}{l}104 \pm 3 \\
189 \pm 15\end{array}$ & $\begin{aligned} 99 & \pm 10 \\
173 & \pm 8\end{aligned}$ & $\begin{aligned} 65 & \pm 1 \\
160 & \pm 10\end{aligned}$ & $\begin{array}{c}50 \pm 2 \\
145 \pm 12\end{array}$ \\
\hline TW & $\begin{array}{l}\mathbf{C} \\
\mathbf{A}\end{array}$ & $\begin{aligned} 92 & \pm 8 \\
147 & \pm 15\end{aligned}$ & $\begin{array}{c}83 \pm 4 \\
156 \pm 11\end{array}$ & $\begin{array}{r}62 \pm 5 \\
152 \pm 9\end{array}$ & $\begin{array}{c}55(1) \\
149 \pm 14\end{array}$ \\
\hline ITW & $\begin{array}{l}\mathrm{C} \\
\mathrm{A}\end{array}$ & $\begin{array}{r}76 \pm 2 \\
144 \pm 5\end{array}$ & $\begin{array}{c}90 \pm 6 \\
152 \pm 13\end{array}$ & $\begin{array}{c}69 \pm 2 \\
153 \pm 10\end{array}$ & $128 \pm 22$ \\
\hline
\end{tabular}

\section{CONCLUSIONS}

In this study we wanted to show the different roles played by $\mathrm{pH}$ and divalent cations in the control of physical properties of egg white. Thus, we hoped that $\mathrm{pH}$ would increase in acidotic eggs after oviposition, while divalent cation content would 
remain high. While the second proposal has been shown to be true, the first was not. So, we cannot judge which parameter ( $\mathrm{pH}$ or divalent cation content) is most important in preventing natural thinning of egg white. However, our results demonstrate that natural thinning does not necessarily occur very quickly after laying, even in normal storage atmosphrere. It can be argued that metabolic acidosis is not of practical use since it decreases egg shell strenght. That is undoubtedly true; so we must find another way to modify $\mathrm{pH}$ and/or the divalent cation content of egg white.

Reçu pour publication en août 1975.

\title{
RÉSUMÉ
}

\author{
LIQUÉFACTION RETARDÉE DE I'AIBUMEN DANS LES GEUFS \\ PROVENANT DE POULES EN ACIDOSE MÉTABOLIQUE
}

\begin{abstract}
On sait que la structure physique de l'albumen lors de la ponte de l'œuf est liée, non seulement à son contenu en certaines protéines, mais aussi en cations minéraux divalents et au $\mathbf{p H}$. Ces paramètres peuvent en particulier être modifiés lorsque la Poule est placée en acidose métabolique. Il est encore mieux connu que l'albumen se liquéfie normalement lorsque l'œuf est conservé après oviposition. Le but du présent travail est de vérifier si l'action bénéfique de l'acidose se poursuit après l'oviposition et d'étudier quels paramètres en sont éventuellement responsables.

I92 œufs ont été étudiés provenant de I 6 poules W'arren dont la moitié était en acidose métabolique. L'étude s'est située soit juste après l'oviposition, soit, après $2, I_{4}$ ou 28 jours de stockage à $20^{\circ} \mathrm{C}$ (3 œufs par poule et par stade).

Le score moyen des unités Haugh des œufs témoins (fig. I) chute de plus de 40 points lorsque l'œuf est conservé 2 semaines; dans le même temps la décroissance est inférieure à Io points pour les oeufs produits en acidose. Ce maintien presque absolu des propriétés physiques de l'albumen s'accompagne d'une stabilité de pression osmotique des trois zones de l'albumen (fig. 2). De même le $\mathrm{pH}$ de ces zones (fig. 3) reste inférieur à 8,0 après 4 semaines de stockage des œufs d'acidose alors qu'il dépasse 8,5 après 2 jours et 9,0 après 2 semaines de conservation des œufs témoins.

L'étude des cations monovalents $\mathrm{Na}$ et $\mathrm{K}$ (tabl. 3) confirme des résultats antérieurs suivant lesquels les mouvements d'eau intervenant dans l'albumen après la ponte sont effectués à concentration sodique constante. Plus intéressante est l'observation des cations divalents (tabl. 4 ) dont la teneur reste constante dans les oufs provenant des poules en acidose (où elle est initialement plus élevée) alors qu'elle diminue de $80 \mathrm{p}$. Ioo (pour $\mathrm{Ca}$ ) ou $5^{\circ} \mathrm{p}$. Ioo (pour $\mathrm{Mg}$ ) dans les œufs témoins.
\end{abstract}

Ces résultats indiquent:

- que la baisse de $\mathrm{pH}$ des œufs d'acidose est due à une surcharge d'acide fixe et non de $\mathrm{CO}_{2}$ qui serait perdu pendant une conservation ultérieure;

- que la liquéfaction de l'œuf pendant le stockage peut être très ralentie même en atmosphère non contrôlée.

Ils ne permettent pas à l'opposé de savoir qui, du $\mathrm{pH}$ ou des cations divalents, joue le rôle essentiel dans la préservation des propriétés physiques de l'abumen puisque ces deux paramètres sont simultanément stabilisés dans les cufs produits sous acidose.

\section{REFERENCES}

Hall K. N., Helbacka N. V., I959. Improving albumen quality. Poult. Sci., 38, I II-II4.

HaUgh R. R., 1937. The Haugh Unit for measuring egg quality. U.S. Egg Poult. Mag., 43, $552-555$.

Hunt J. R., Aitken J. R., I962. The effect of ammonium and chloride ions in the diet of hens on egg shell quality. Poult. Sci, 41, 434-438. 
Monsey J. B., Robinson D. S., 1974. The relationship between the concentration of metals and the rate of liquefaction of thick egg white. Brit. Poult. Sci., 15, 369-373.

Robinson D.S., I972. Egg white glycoproteins and the physical properties of egg white. In : Egg formation and production, p. 65-86. Edit. Freeman, B. M. and LAke, P. E. Brit. Poult. Sci. Ltd, Edinburgh.

Robinson D. S., MONSEY J, B., 1972. Changes in the composition of ovomucin during liquefaction of thick egg white. The effect of ionic strength and magnesium salts. J. Sci. Food. Agric., 23, 893-904.

Romanoff A. L., Romanoff A. J., 1949. The avian egg. Wiley and Sons Inc., New York and Chapman and Hall Ltd, London.

Sauveur B., I969. Étude de la composition électrolytique des différentes zones de l'albumen de l'œuf chez deux races de poule. Ann. Biol. anim. Biochim. Biophys., 8, 563-573.

Sauveur B., r97o. Acidoses métaboliques expérimentales chez la Poule pondeuse. 2. Action sur la composition minérale de l'albumen de l'œuf. Ann. Biol, anim. Biochim. Biophys., 10, 8I-Ioo.

Sauveur B., I97I. Répartition des électrolytes et du glucose dans l'œuf conservé sous o ou 2 p. 100 de gaz carbonique. Ann. Biol. anim. Biochim. Biophys., 11, 625-643.

Sauveur B., I973a. Reconstitution in vitro du déterminisme des propriétés physiques de l'albumen de l'œuf. Journées Rech. avic. cunic. Paris, 317-321.

Sauveur B., I973 b. Répartition des cations liés et diffusibles dans les trois zones de l'albumen de l'ouf. 4th Europ. Poult. Conf., London, 477-484.

Sauveur B., 1974. Recherches sur la fraction hydro-minérale de l'albumen de l'auf de Poule. Infuence de certaines variations de l'équilibre acido-basique. Thèse de Doctorat, Tours. 